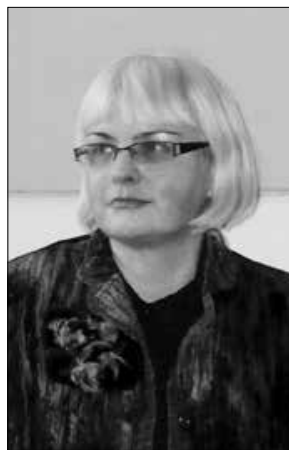

https://doi.org/10.24101/logos.2017.55

RAIMONDA SIMANAITIENE

Vytauto Didžiojo universitetas, Lietuva

Vytautas Magnus University, Lithuania

\title{
ASOCIACIJŲ ŽAISMĖS IR KÜRINIŲ IŠTARMĖS DAILININKO RIMVYDO MULEVIČIAUS PAVEIKSLUOSE
}

\author{
The Abundance of Associations and Narrative of Creations \\ in Artist's Rimvydas Mulevičius Pictures
}

\begin{abstract}
SUMMARY
Rimvydas Mulevičius is known as a long time professor of the Vilnius Art Academy and the Kaunas Faculty Drawing Studio, He is a stained-glass artist, skilful drawer, and a participant of many watercolour and graphics exhibitions in Lithuania and abroad. The plastic expression which unfolds in the artists' paintings should probably be referred to as realistic, although his drawings undoubtedly gain an associative, surrealistic nature as well because of a particular interpretation of chosen themes, plots and characters. Some of the themes (Christianity, architecture) in R. Mulevičius creations are more traditional and classic, therefore, their representation is quite casual. Meanwhile, other plots (autoportrait, fragments of human anatomy) reflect the artist's specific appreciation of the world and the dominating surrealistic principle of visualisation, which accounts for the paintings' originality and suggestibility. Therefore this article will be dedicated to a thorough analysis of R. Mulevičius creations: the display of artists' metaphorical, associative outlook, thematic spectrum of production. It will also highlight the plastic tools of expression and the specifics of artistic representation.
\end{abstract}

\section{SANTRAUKA}

Rimvydas Mulevičius yra žinomas kaip ilgametis Vilniaus dailès akademijos Kauno fakulteto profesorius, Piešimo studijos vadovas, taip pat kaip vitražo dailininkas, meistriškas piešějas, daugelio akvarelès ir grafikos parodų Lietuvoje bei užsienyje dalyvis. Menininko paveiksluose atsiskleidžiančią plastinę raišką veikiausiai turètume įvardinti kaip realistinę, tačiau jo sukurti paveikslai dẻl pasirinktų temų, siužetų ir personažų traktuotės neabejotinai iggyja asociatyvų, siurrealistini pobūdị. Vienos R. Mulevičiaus pamėgtos temos (krikščionybės, architektūros) yra tradiciškesnès, klasikinės, tad ir ju plastiniai įvaizdinimai ịprastesni. O kiti siužetai 
(autoportretu, fragmentuotos žmogaus anatomijos) atspindi itin specifinį menininko pasaulio pajautimą bei dominuojantį siurrealistinį vaizdavimo principą, pagrindžiantị jo paveikslų originalumą ir įtaigumą. Taigi šis straipsnis skirtas išsamesnei dailininko Mulevičiaus kūrybos analizei: tiek jo metaforiško, asociatyvaus pasaulèvaizdžio, kūrinių tematinio spektro atsklaidai, tiek ir plastinių išraiškos priemonių, meninio vaizdavimo specifikos išryškinimui.

\section{IVADAS}

Rimvydo Mulevičiaus studijos ir kūrybinis kelias prasidèjo nuo monumentalaus meno - vitražo - specialybès pažinimo Vilniaus dailès akademijoje prof. Algimanto Stoškaus studijoje ${ }^{1}$. Daugiausiai vitražų menininkas sukūrè jaunystèje. Igyvendino nemažai monumentalių kūrinių visuomeniniuose ir sakraliniuose pastatuose. Iš ju galètume paminèti kelis itin didelius ansamblius Kauno Palemono, Gargždų, Grigiškių, Jokūbavo bažnyčiose. Tačiau šiame straipsnyje R. Mulevičiaus vitražų nenagrinèsime, nes pastaraisiais dešimtmečiais kiek sumenkus vitražo reikmei šiuolaikinëje architektūroje, dailininkas èmėsi ieškoti kitų meninių terpių. Todèl šiandien menininką pažistame kaip universalu, jau daugeli metu ivvairiose dailès srityse dirbantį kūrëją. Autorius yra sẻkmingai ìvaldęs nemažai tradicinių techniku, savitai jas taiko. Ypač tai galime pasakyti apie eksperimentus piešinio srityje, mat jis piešini iš pagalbinès paveikslo sukūrimo priemonès neabejotinai pakylèjo i̇ pagrindinę, ypatingu kūrybingumu pasižyminčią meninę raišką. Žvelgdami i dailininko piešinius regime grafitu, sangina, tušu ar tiesiog paprastu pieštuku kuriamus stebuklus: linijos ir štrichai čia pulsuoja, virpa, kuria erdvès ir laikinumo nuojauta, tikslina kontūrą, išreiškia asmenybės charak- terị, perteikia panašumą, kelia asociacijas... Menininko piešiniai tampa savarankiškais kūriniais, kuriuos vertiname nẻ kiek ne mažiau nei rafinuotus grafikos darbus. Aptardami pastaruosius vèl galime prisiminti visas paminètas ypatybes, tačiau čia matome dar ir papildomą demenį - amato meistrystę: akvatintos ar oforto inspiruotą šviesos šešèlio žaisma, atspaudo nuotaiką kurianti èsdinima, giliaspaudès tonų sodrumą, preciziškiausiu štrichų ir kontūrų dermę. Akvarelèse menininkas taip pat išlieka originalus, sąmoningai nutolsta nuo lietuviškosios akvarelès mokyklos, kuriai dažniausiai būdingi sulieti, apibendrinti potèpiai, koloristiniai viražai, abstraktūs vaizdai ${ }^{2}$. Mulevičiaus akvarelèms netrūksta spalvinių tonų dermiu, dažo liejimo virtuoziškumo, tačiau jose visų pirma išryškèja konkretus piešinys ir skleidžiasi įvairios istorijos. Galima teigti, jog akvarelèmis dailininkas tampa išskirtiniu, i̇domiu pasakotoju, o spalvu jam prireikia tam, kad sustiprintų savo siužetų nuotaikas, suteiktu papildomu prasmiu ar estetinių verčių. Tobulas amato meistriškumas puikiai matyti ir pastaraisiais metais pamėgtoje liejimo technikoje - kinišku tušu igyvendintuose kūriniuose, kuriuose vos keli potėpiai nulemia visą meninio vaizdo sandarą ir turtingumą. 
Taigi rašant ši straipsni buvo užsibrèžtas tikslas - išnagrinèti parodinę dailininko Mulevičiaus kūrybą ìsigilinant $i$ jo darbu plastinę sandarą ir aptariant autoriaus pamėgtas originalias kūrinių temas bei paveiksluose atsiskleidžiančias menines idejas. Todèl buvo pasitelkti naratyvinès ir formaliosios analizės metodai, taip pat ne kartą vykę interviu su dailininku.

\section{"APIE SAVĘS IR KITŲ MENININKŲ İAMŽINIMĄ"}

Mulevičiaus darbai išsiskiria stulbinamu realistiškumo ir fantasmagoriju deriniu. Dailininko kūriniuose atsiskleidžia nuolatinis gilinimasis ị save, regima asmeninių išgyvenimų sąsaja su amžinais, globaliais klausimais, tokiais kaip tikejjimas, žmogiškumas, bičiulystè... Šios menininkui svarbios temos ryškejja per jo pamėgtus siužetus ir motyvus, kūriniuose nuolatos atsikartojančius, kartkartemis tarsi primirštamus ir atsikvèpus vèl plètojamus iš naujo. Stropi ir atidi aplinkos ir savęs analizè, regis, paprastas, bet tinkamai pasirinktas naratyvas žiūrovui atveria turiningą realybès ir fantaziju pasauli. Tai, kad skirtingais būdais sukurtuose darbuose kartojasi ir iš vienų paveikslų ì kitus persikelia tos pačios temos ir motyvai, mene nėra naujiena. Panašiu analogu galètume atrasti kad ir XX a. didžiujju modernistų dailèje (pavyzdžiui, Pablo Picasso, Salvadoro Dali, Joano Miro ar Marco Chagallo darbuose) ${ }^{3}$.

Iš tokiu pasikartojančių temų visų pirma galètume išskirti Mulevičiaus autoportretus ir artimiausių draugu (dažniausiai menininkų) akvarele nulietus, estampuose atspaustus ar tiesiog pieštuku užfiksuotus atvaizdus. Save portretuose autorius dažniausiai vaizduoja groteskiškai, netgi ekscentriškai: dengiantị veidą rankomis, išnyrantị iš ausies ertmės i̇ išorę, ryjantị kaukolę, kartais persikūnijantị i gyvulì, neretai - šlykštu, grèsmingą, pilną geidulių. Beje, toks žmogaus ir gyvulio palyginimas itin dažnas ịvairiuose Mulevičiaus kūriniuose. Menininkas tarsi laikosi froidistinès pozicijos, teigia, kad žmogaus gyvenimas - ne visada teisingas, tad gyvuliški poelgiai, instinktai jo kūryboje prisimenami neatsitiktinai ${ }^{4}$.

Portretų serijoje matome daugeli kūrëjų, kolegų: ne kartą atvaizduotus poetus Gintarą Patacką, Tautvydą Marcinkevičiūtę, aktorių Viktorą Šinkariuką, skulptorius Evaldą Pauza, Vytautą Umbrasa, tapytoją Joną Juodzevičiu ir daugeli kitų. Šių kūrëjų portretai tikroviški, charizmatiški, kartais hipertrofuoti. Portretuose pasitelkti atributai, simboliai, nuotaikos itin būdingi, atspindintys minètu menininku kūrybos ir gyvensenos nuolatini stebejjimą. Pasak R. Mulevičiaus, su šiais kūrejjais ji sieja „tikra bičiulystė, patikrinta lyg senas vynas. Kai kurių bičiuliu, deja, jau nebèra gyvuju tarpe, bet atmintyje išliko jų vaizdiniai, prisiminimai, žvilgsniai, bendravimo akimirkos“. I klausimą „,kodèl autorius taip nuosekliai kuria savo draugu portretus?" Mulevičius atsako, kad greičiausiai tai lemia vidinès ramybès stoka, dvasinis alkis, noras išreikšti bendravimo tikrumą ${ }^{5}$. 


\section{"APIE ŽMOGAUS KÜNO IৃPRASMINIMĄ"}

Dailininkui taip pat itin svarbi yra krikščionybès tema. Daugelis Šv. Rašto personažu, ikūnijamų menininko, buvo surasti ir vizualizuoti dar ankstyvojoje kūryboje, kai jam ne kartą teko igyvendinti vitražu projektus bažnyčioms ${ }^{6}$. Tuomet menininko labiausiai pamėgti ir dažniausiai stikle vaizduoti Kristaus ir Marijos ikonografiniai tipažai. Šiandien šie personažai dažniau piešiami, o prototipu jiems tampa pažistamos moterys ir vyrai: kartais jie idealizuojami, „pakylejami“, o kartais - vizualiai deformuojami, skausmingai iškreipiami. Jų vaizdiniuose atsispindi itin plati žmogišku jausmų skalè, taip pat ir dieviškoji rimtis, susikaupimas. Krikščioniškąją temą paveiksluose papildo buvimo ir mirties apmąstymai. Juos išvystame meistriškuose R. Mulevičiaus grafikos atspauduose, piešiniuose ar kinišku tušu nulietuose darbuose ${ }^{7}$, kuriuose dominuoja žmogaus griaučiu, gyvūnu kaukoliu (sunykimo ir baigties) motyvai. Pastarieji įvaizdžiai atrodo bauginantys, grèsmingi, simboliški. Taip pat šią temą įtikinamai pratęsia dailininko kūriniai, paremti žmogaus anatomija. Būdamas puikus piešejas, gerai išmanantis anatomiją ${ }^{8}$ Mulevičius imasi sudètingų figūrinių rakursų, drąsiai eksperimentuoja su žmogaus atvaiz$\mathrm{du}$, įdomiai stilizuoja figūras ${ }^{9}$.
Esmingiausiu anatomijos elementu Mulevičiaus kūryboje yra tapusios rankos. Menininkui rankos apskritai reikšmingas įrankis, jų svarba kuriant neabejotina. Estampuose, piešiniuose perteiktos rankos yra itin išraiškingos, įvairialypės: kuo kruopščiausiai „išknebinètos“, išraižytos smulkiausiomis raukšlelėmis, su pavaizduotais sąnarių krumpliais, dengiančios veidus, kviečiančios stebėtis, imantrios savo lanksčia forma, grakščios ir susenusios, susikaupiančios ir atsiveriančios maldoje. Menininko kūryboje nuolatos išryškëja ir ausies motyvas. Šis motyvas stebètojui primena žmogiško komunikavimo poreiki, tarpusavio susikalbẻjima, kito nuomonès išklausymą, žmogaus ir kultūros santykio suvokimą. Visi kūriniai, kuriuose dominuoja žmogaus kūno fragmentai (akys, ausys, rankos, kojos) - itin asociatyvūs, pilni įvairiu perversiju, transformaciju, įmantriu vaizduojamuju jungčių. Tokiomis jungtimis gali tapti galvos (ar figūros) išnirimas iš ausies, galvos ir koju derinys, pasitelktas perteikiant keistą siurrealistinį žmogaus pavidalą. Vienas i̇domiausių perkeltine prasme pateiktų šios temos ịvaizdinimųi gandus įsivèlusios romènų deivès Famos $^{10}$ triptikas, kuriame žmogaus anatomijos objektus ir jų santykius traktuojame kaip šiurkštaus komunikavimo dėmenis.

\section{„APIE KASDIENYBÉS POTYRIŲ IVAIZDINIMĄ"}

Analizuojant R. Mulevičiaus kūrybą būtina paminèti asociacijų kupina, daugeli metų kuriamą ciklą, pavadintą „Piešiniai iš bloknoto". Ši ciklą (o tiksliau, daugybę piešinių, fiksuojamų nuolat pildomame ir keičiamame bloknote) dailininkas piešia darbe, konferenciju, posẻdžių metu, namie - vakarodamas, ilsèdamasis. Panašiai kaip Monmartre kūręs Henri de Toulouse'as Lautrecas, jis 
nuolatos fiksuoja minti ar aplinką. Minètus eskizus menininkas vadina „pasąmonès brūkšniais". Sakosi, jei netektų galimybès piešti, negalètų išlikti ramus ${ }^{11}$. Šių piešinių atmosfera ir personažai dažniausiai igyja makabriška, fantasmagorišką forma, čia nuolat jungiasi keistu gyvių ir žmonių figūros. Neapibrèžtose erdvėse veikiantys herojai primena mitines būtybes, o jei tiksliau - atspindi menininko galvoje iškilusį iliuziju pasauli, kurio personažai kupini ydų ir troškimų. Jų santykiuose vyrauja kraštutinumai: agresija, keistumas, lyriškumas, tikèjimas, idealizmas, seksualumas. Visi šie padarai - materializavęsi nerealių, siurrealistinių vizijų atspindžiai, balansuojantys tarp asmeniškumo, intymumo ir visuotinai kultūriškai suvokiamų archetipų. Menininkas šiuos piešinius ir ju herojus šiltai vadina „baibokais", yra parengęs ne vieną ju parodą ${ }^{12}$. „Baiboku“" parodose eksponuoti piešiniai - improvizuoti, greiti, staigūs, nupiešti remiantis efektu „čia ir dabar". Dailininkas aiškina, kad studentų pomègis paskaitų metu paišyti užrašuose sarkastiškai vadinamas „nuobodizmu“"13. Mulevičius savo kuriamuose „,baibokuose" išlaiko analogišką kūrybos principa, bet skatina su didesniu atidumu pasižiūrèti i dailininkų „užrašų ” paraštes kaip ì ypatingo kūrybingumo terpe $e^{14}$.

Dar viena Mulevičiui svarbi tema miestas, jo erdvè, pastatai, su kuriais (beje, panašiai kaip ir su žmonėmis) ji susiejo likimas. Tai visu pirma sena apleista žydų škala Kaune, kur ilgą laiką buvo menininko dirbtuvès ir kurioje jis gyveno jaunystejje. Taip pat senosios Kauno bažnyčios, vienuolynai, pro kuriuos menininkas kasdien grižta namo. Visa ši architektūra - tiek apleista, griūvanti, tiek prikelta, atnaujinta gyvenimui - Mulevičiaus kūriniuose fiksuojama kruopščiai, detaliai, galima sakyti, dokumentiniu metodu. Tačiau iš pastatų rakursų, detaliu, fragmentų traktuotès jaučiame šilta, gyvą menininko santyki su vaizduojamu objektu. Kartais prisimenami tie miestai, kuriuose menininkas kažkada lankèsi, stažavosi, kūrè. Vienas tokių - Sankt Peterburgas. Jis piešiamas jau kitaip: eksploatuojant metaforišką vaizdavimo būdą, fantazuojant, prisimenant literatūrinę rusų klasiką. Sankt Peterburgo panoramose dailininkas tarsi perteikia dostojevskiškąsias pasąmonès vizijas, sklandančias šio poetiško miesto erdvėse.

\section{IŠVADOS}

Apibendrinant Mulevičiaus kūrybos bruožus, norisi akcentuoti, kad menininko išskirtinumą ir savitumą šiandieninèje dailejje lemia jo paveiksluose ryškëjanti meistriška realistinė plastikos maniera, savita, su žmogaus atvaizdo, figūros fragmentacija, kūno anatomijos perversija susieta tematika ir meninio vaizdo metaforiškumas, fantastiškumas. Nūdien tai gana retas, bet itin ittaigus derinys.
Autoriaus gvildenamų bendražmogiškų siužetų siurrealistinis ịprasminimas kūriniuose, ju traktuotès paveikumas $\mathrm{Mu}$ levičiaus kūrybą svariai įrašo ị klasikinès dailès konteksta, o jo paveikslu stebètoją ittraukia $\mathfrak{i}$ itin turtingu asociacijų ir palyginimu gelmes, kviečia permąstyti savąsias patirtis. Tai neabejotinai gilių nuostatų ir amžinųjų vertybių sklaidą atspindinti kūryba. 


\section{Literatūra ir nuorodos}

1 Apolonija Valiuškevičiūtè, Kauno dailès institutas 1940-2000. Kaunas: J. Petronio leidykla, 2002, p. 480.

2 Akvarele: albumas. Vilnius: Vaga, 1986, p. 5.

${ }^{3}$ Herbert Read, Trumpa moderniosios tapybos istorija. Vilnius: Vaga, 1997, p. 58.

${ }^{4}$ Iš straipsnio autorès pokalbio su dailininku. 20170322.

${ }^{5}$ Raimonda Simanaitienè, Projektas "Intimus" VDA "Akademijos" galerijoje < http://www.kamane.lt/Kamanes-tekstai/Daile/Projektas-IntimusVDA-Akademijos-galerijoje >

${ }^{6}$ Kauno dailininkai. Pédsakai laike. Kaunas: Kauno dailininku paramos fondas, p. 316.

7 Tokius piešinius menininkas pradèjo kurti ikvvèptas sūnaus studijų. R. Mulevičiaus sūnus Adomas mokèsi sinologijos Šanchajaus Fudan universitete, gyvena ir dirba Kinijoje. Taigi dalis pastaruju metų dailininko darbų yra sukurti išbandant pas mus naują ir ypatinga, bet Kinijoje paplitusią techniką: piešiniai nupiešti kinišku tušu, bambukiniais teptukais ant ryžių popieriaus.

${ }^{8}$ Beje, VDA KF profesorius studentams dèsto ne tik piešima, bet ir anatomijos kursą.
9 Kauno menininkai. Kaunas: Kauno meno fondas, 1996, p. 82.

10 Antikoje Fama žinoma kaip gandu perteikejja, reputacijos, taip pat ir maldu deivè. Johannes Irmscher, Renate Johne, Lexikon der Antike. Leipzig: VEB Bibliographisches Institut Leipzig, 1987, S. 176.

11 Iš straipsnio autorès pokalbio su dailininku. 20170224.

12 Žr.: http://kamane.lt/Naujienos/2013-metai/Lapkritis/ Daile/Prof-Rimvydo-Muleviciaus-paroda-Baibo-Q

${ }^{13}$ Iš straipsnio autorès pokalbio su dailininku. 20170224.

14 Čia galètume prisiminti faktus, kad ivvairiais gyvenimo tarpsniais dirbdami mokykloje ar akademijoje, pertraukų metu groteskiškus eskizus-fantasmagorijas piešė ir kiti garsūs menininkai (pavyzdžiui, Antanas Martinaitis, Edmundas Saladžius, Rimantas Šulskis, Ričardas Vaitiekūnas ir t. t.). Šių dailininkų „paraščių“ piešiniai šiandien taip pat neretai eksponuojami parodose kaip itin įdomi jų kūrybos (neretai ir kolektyvinès, kada vieno kūrèjo pradètą piešini pabaigdavo kitas) dalis. 